\title{
Sistem Monitoring Inkubator Bayi
}

\author{
Qory Hidayati \\ Program Studi Teknik Elektronika, \\ Jurusan Teknik Elektro Politeknik \\ Negeri Balikpapan, \\ Balikpapan, Indonesia \\ qory.hidayati@poltekba.ac.id
}

\author{
Nur Yanti \\ Program Studi Teknik Elektronika, \\ Jurusan Teknik Elektro Politeknik \\ Negeri Balikpapan, \\ Balikpapan, Indonesia \\ nur.yanti@poltekba.ac.id
}

\author{
Nurwahidah Jamal \\ Program Studi Teknik Elektronika, \\ Jurusan Teknik Elektro Politeknik \\ Negeri Balikpapan, \\ Balikpapan, Indonesia \\ nurwahidah.jamal@poltekba.ac.id
}

\begin{abstract}
Kelahiran prematur adalah kelahiran yang terjadi sebelum minggu ke 37 atau lebih awal dari hari perkiraan lahir. Berbagai masalah yang dapat ditimbulkan oleh kelahiran prematur. Bayi berat badan lahir rendah (BBLR) adalah bayi baru lahir yang berat badan lahirnya pada saat kelahiran kurang dari 2500 gram. Dahulu neonatus dengan berat badan lahir kurang dari 2500 gram atau sama dengan 2500 gram disebut prematur. Bayi prematur mempunyai resiko kematian yang lebih tinggi dibandingkan dengan bayi yang lahir cukup bulan. Banyak faktor yang mempengaruhi meningkatnya angka kematian bayi prematur. Salah satunya yaitu minimnya pengawasan kondisi tubuh bayi prematur setelah lahir. Pada penelitian ini, dibuat sebuah sistem yang dimplementasikan pada inkubator yaitu sistem monitoring. Sistem monitoring menggunakan bluetooth sebagai media komunikasi untuk monitoring. Untuk monitoring bayi, digunakan load cell untuk mengukur berat bayi, DS18B20 untuk mengukur suhu tubuh bayi, dan pulse sensor untuk mengukur detak jantung bayi.
\end{abstract}

Kata Kunci-Monitoring, suhu, load cell, pulse sensor, bluetooth

Abstract-Premature births are births that occur before the 37th week or earlier than the estimated day of birth. Various problems that can be caused by premature birth. Low birth weight babies ( $L B W)$ are newborns whose birth weight is less than 2500 grams at birth. Formerly a neonate with a birth weight of less than 2500 grams or equal to 2500 grams is called premature. Premature babies have a higher risk of death compared to babies born at term. Many factors affect the increase in premature infant mortality. One of them is the lack of supervision of the condition of the body of premature babies after birth. In this study, a system was implemented which was implemented on an incubator, a monitoring system. The monitoring system uses bluetooth as a communication medium for monitoring. For baby monitoring, a load cell is used to measure the baby's weight, DS18B20 to measure the baby's body temperature, and a pulse sensor to measure the baby's heart rate.

Keywords-Monitoring, temperature, load cell, pulse sensor, bluetooth

\section{Pendahuluan}

Menurut Widjayanegara dalam usia kehamilan merupakan salah satu hal yang dapat mempengaruhi kelangsungan hidup janin dan kualitas hidupnya [1]. Umumnya kehamilan disebut cukup bulan bila berlangsung antara 37- 41 minggu di hitung dari hari pertama siklus haid terakhir pada siklus 28 hari.
Sedangkan persalinan yang terjadi sebelum usia kandungan mencapai 37 minggu disebut dengan persalinan prematur.

Estimasi yang reliabel untuk angka kelahiran prematur tidak tersedia untuk Indonesia. Meskipun demikian, WHO (2012) mencatat bahwa angka kejadian kelahiran prematur di Indonesia pada tahun 2010 adalah 15,5 per 100 kelahiran hidup dan menempatkan Indonesia di posisi ke-9 tertinggi dari 184 negara. Angka ini cukup besar jika dibandingkan dengan negara Belarus yang menempati urutan terakhir dengan jumlah kelahiran prematur sebesar 4,1 per 100 kelahiran hidup. Sementara itu, jika dibandingkan dengan negara ASEAN lainnya, Indonesia memiliki angka kejadian kelahiran prematur tertinggi, kemudian diikuti oleh Filipina (14,9 per 100 kelahiran hidup), dan Myanmar (12,4 per 100 kelahiran hidup) .

Banyak faktor yang mempengaruhi kesehatan dari bayi prematur, diantaranya yaitu suhu, berat badan, detak jantung, dan kadar bilirubin darah bayi. Bayi berat badan lahir rendah ( BBLR ) adalah bayi baru lahir yang berat badan lahirnya pada saat kelahiran kurang dari 2500 gram. Dahulu neonatus dengan berat badan lahir kurang dari 2500 gram atau sama dengan 2500 gram disebut prematur. Pada tahun 1961 oleh WHO semua bayi yang baru lahir dengan berat lahir kurang dari 2500 gram disebut Low Birth Weight Infants ( BBLR) [2].

Tak hanya berat badan, tapi detak jantung neonatus perlu juga diawasi untuk memastikan kesehatan bayi. Umumnya kecepatan detak jantung orang dewasa lebih rendah daripada bayi. Detak jantung bayi baru lahir umumnya berkisar antara 120 - $160 \mathrm{bpm}$, bergantung dari aktivitas bayi. Misalnya ketika menangis atau kesakitan dapat mencapai 180 bpm (www.parenting.co.id, 2019). Penelitian sebelumnya yang terkait dengan penelitian yaitu dengan melakukan pengembangan inkubator bayi dengan sistem pemantaun remote [3] dan komunikasi wireless [4]. Maka dilakukan penelitian Sistem Monitoring Inkubator Bayi.

\section{BAHAN DAN METODE}

Metode proses penelitian diawali dengan perancangan alat dan aplikasi yaitu membuat desain casing alat dan skematik rangkaian sensor. Kemudian dari rancangan tersebut selanjutnya dilakukan pembuatan secara nyata untuk perakitan alat dan program-program, serta rangkaian yang digunakan. Setelah itu, dilakukan pengujian alat secara terpisah dan menyeluruh dalam satu sistem. analisis kesalahan yang ada sangat diperlukan agar rancangan alat dapat bekerja secara maksimal, sehingga perlu dilakukannya uji coba hingga mencapai hasil yang diinginkan. 
Monitoring inkubator bayi ini bekerja berdasarkan pendeteksian berat badan, detak jantung, dan suhu bayi dimana tiga indikator tersebut akan dikirimkan nominal data yang diukur menggunakan sebuah bluetooh module. Gambar 1 merupakan diagram blok inkubator bayi untuk proses perancangan alat.

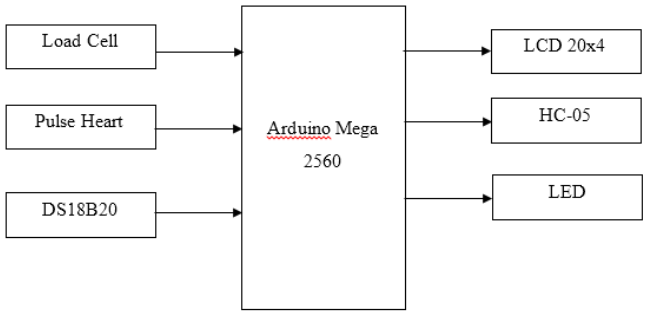

Gambar 1. Blok diagram inkubator bayi

Inkubator akan bekerja menggunakan Arduino Mega 2560 sebagai pengolah data. Inkubator akan menerima masukan dari sensor load cell, pulse heart sensor, dan hasil pengukuran akan dikirimkan oleh Bluetooth module ke smartphone dan LCD 20x4. LED dan buzzer digunakan sebagai indikator apabila detak jantung berada di bawah nilai yang ditentukan. Gambar 2 merupakan diagram alir inkubator bayi untuk proses perancangan alat.

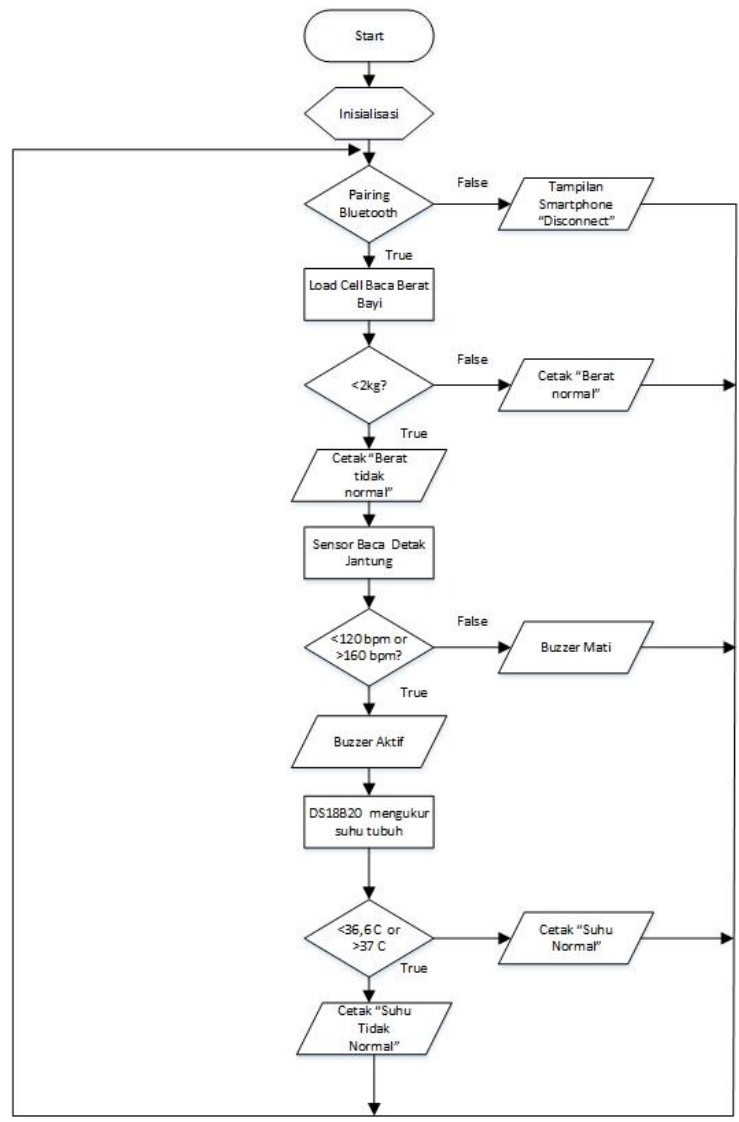

Gambar 2. Diagram Alir inkubator bayi

Dari gambar 2 sensor load cell diberikan nilai acuan sebesar 2 - 2,5 kg, dimana ketika berat bayi tidak sama dengan nilai tersebut maka tampilan pada smartphone akan menunjukkan "Berat belum normal". Namun ketika berat bayi sama dengan nilai acuan maka tampilan pada smartphone akan menunjukkan "Berat sudah normal”.

Pulse heart rate sensor diberikan nilai acuan sebesar 120 - 160 bpm, dimana ketika kecepatan detak jantung tidak sama dengan nilai tersebut maka sensor akan mengaktifkan buzzer dan LED indikator. Namun ketika kecepatan detak jantung sama dengan nilai acuan maka buzzer dan LED indikator akan tetap mati. Adapun sensor suhu diberikan batas nilai acuan sebesar 36,6pC - 37oC, dimana ketika suhu bayi tidak sama dengan nilai tersebut maka tampilan pada aplikasi akan menampilkan "Suhu Tidak Normal”. Namun ketika nilai suhu bayi sama dengan nilai acuan maka tampilan pada aplikasi akan menunjukkan "Suhu Normal”.

Selanjutnya perlu dilakukan penambahan monitoring pendeteksi bilirubin [5] dan kendali dengan Intelligent Control System [6] menggunakan IOT [7].

\section{A. Sensor Load Cell}

Load Cell adalah sebuah jenis alat uji beban / tranduscer yang memiliki kemampuan dalam mengubah suatu gaya menjadi suatu sinyal listrik. Alat ini memiliki prinsip deformasi sebuah material akibat adanya suatu tegangan mekanis yang bekerja.

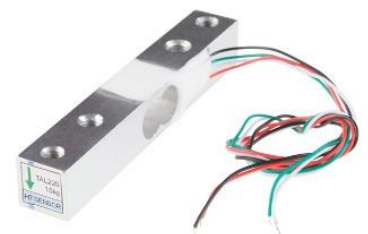

Gambar 3. Load Cell

Dalam menetukan tegangan mekanis harus dilandaskan pada hubungan antara tegangan mekanis dan deformasi yang disebut regangan. Load cell yang paling sederhana adalah terdiri dari sensor strain gauge dengan lapisan bending beam dan dilengkapi dengan elemen tambahan (housing, sealing, dll) untuk melindungi elemen dari strain gauge.

Load cell dapat bekerja apabila diberi beban pada sebuah inti besi yang terdapat sebuah sensor untuk mengubah suatu gaya ke sinyal listrik dengan mengubah nilai resistansi akibat tekanan yang disebut dengan Strain Gauge. Umumnya Load cell memiliki empat kabel yang terdiri dari dua kabel eksitasi dan dua kabel keluaran.

Load cell sering diaplikasikan pada suatu timbangan digital. Saat proses penimbangan, beban yang diukur akan mengakibatkan reaksi perubahan bentuk secara elastik pada Load cell. Selain digunakan oleh ibu rumah tangga dan toko kelontong, timbangan digital juga digunakan oleh beberapa pemeran industri dan diaplikasikan pada jembatan timbang. 


\section{B. Easy Pulse Plugin}

Prinsip kerja dari Easy pulse plugin sangat sederhana. Sensor memiliki dua sisi, di sisi satu LED dipasang dengan sebuah sensor ambient light dan di sisi lainnya terdapat semacam rangkaian. Rangkaian ini bertugas untuk menguatkan dan meminimalisir noise. LED yang ada di depan sensor di taruh di atas nadi tubuh manusia seperti ujung jari atau telinga.

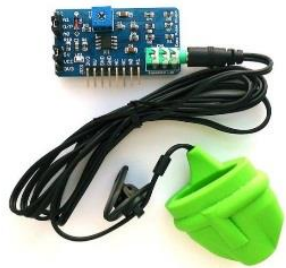

Gambar 4.Easy Pulse Plugin

LED akan memancarkan cahaya yang mengarah ke nadi secara langnsung. Di dalam nadi terdapat aliran darah yang mengalir ketika jantung berdetak, jadi ketika kita memonitor aliran darah kita juga memonitor detak jantung manusia. Jika alirah darah terdeteksi maka sensor ambient light akan menangkap lebih banyak cahaya karena cahaya yang dipancarkan terpantul oleh darah, perubahan kecil yang diterima oleh cahaya akan dianalisa untuk menentukan cepatnya jantung berdetak.

\section{Sensor Suhu DS18B20}

DS18B20 adalah sensor suhu digital seri terbaru dari Maxim IC (dulu yang buat adalah Dallas Semiconductor, lalu dicaplok oleh Maxim Integrated Products). Sensor ini mampu membaca suhu dengan ketelitian 9 hingga 12-bit, rentang $-55^{\circ} \mathrm{C}$ hingga $125^{\circ} \mathrm{C}$ dengan ketelitian $\left(+/-0.5^{\circ} \mathrm{C}\right)$. Setiap sensor yang diproduksi memiliki kode unik sebesar 64-Bit yang disematkan pada masing-masing chip, sehingga memungkinkan penggunaan sensor dalam jumlah besar hanya melalui satu kabel saja (single wire data bus/1-wire protocol). Ini merupakan komponen yang luar biasa, dan merupakan batu patokan dari banyak proyek-proyek data logging dan kontrol berbasis temperatur di luar sana.

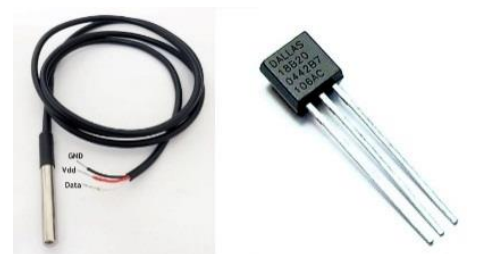

Gambar 5. Sensor Suhu DS18B20

\section{HASIL DAN PEMBAHASAN}

\section{A. Sensor DS18B20}

Sensor DS18B20 ini berperan sebagai pengukur suhu tubuh bayi. Sensor ini dapat mengubah suhu menjadi sinyal 12 bit dalam waktu 750ms. Selain itu, sensor ini juga mampu mengukur suhu dari $-55^{\circ} \mathrm{C}$ sampai $+125^{\circ} \mathrm{C}$.

Pengujian sensor DS18B20 ini dilakukan untuk mengetahui selisih antara modul sensor suhu dengan thermometer tubuh sehingga dapat diketahui seberapa besar tingkat akurasi yang dihasilkan sensor suhu DS18B20. Suhu pada modul sensor ditampilkan pada serial monitor Arduino.

TABEL 1.

HASIL PENGUJIAN SENSOR DS18B20

\begin{tabular}{|c|c|c|c|c|c|}
\hline No & Nama & $\begin{array}{c}\text { Nilai } \\
\text { Suhu } \\
\text { Sensor }\end{array}$ & $\begin{array}{c}\text { Nilai } \\
\text { Suhu } \\
\text { Tubuh }\end{array}$ & Selisih & Error \\
\hline 1 & Restu & $32,25^{\circ} \mathrm{C}$ & $33,8^{\circ} \mathrm{C}$ & 1,55 & $4,8 \%$ \\
\hline 2 & Adit & $32,50^{\circ} \mathrm{C}$ & $33,4^{\circ} \mathrm{C}$ & 0,9 & $2,76 \%$ \\
\hline 3 & Arif & $34,00^{\circ} \mathrm{C}$ & $35,5^{\circ} \mathrm{C}$ & 0,04 & $4,41 \%$ \\
\hline 4 & Intan & $27,30^{\circ} \mathrm{C}$ & $28,6^{\circ} \mathrm{C}$ & 1,3 & $4,76 \%$ \\
\hline 5 & Aqmal & $32,20^{\circ} \mathrm{C}$ & $33,7^{\circ} \mathrm{C}$ & 1,5 & $4,65 \%$ \\
\hline 6 & Bowo & $33,60^{\circ} \mathrm{C}$ & $34,8^{\circ} \mathrm{C}$ & 1,2 & $3,57 \%$ \\
\hline 7 & Tegar & $36,30^{\circ} \mathrm{C}$ & $34,69^{\circ} \mathrm{C}$ & 0,04 & $4,40 \%$ \\
\hline 8 & Wahyudi & $34,88^{\circ} \mathrm{C}$ & $36,0^{\circ} \mathrm{C}$ & 0,03 & $3,21 \%$ \\
\hline 9 & Maulana & $33,50^{\circ} \mathrm{C}$ & $34,8^{\circ} \mathrm{C}$ & 1,3 & $3,88 \%$ \\
\hline 10 & Lana & $34,50^{\circ} \mathrm{C}$ & $36,0^{\circ} \mathrm{C}$ & 1,5 & $4,34 \%$ \\
\hline \multicolumn{7}{|c|}{ RATA - RATA ERROR } & 0,93 & $4,07 \%$ \\
\hline
\end{tabular}

Penggunaan resistor sebesar $4,7 \mathrm{k}$ ohm pada sensor dibutuhkan, untuk memfilter noise yang dibaca oleh suhu. Jika sensor tidak diberi resistor $4,7 \mathrm{k}$ ohm maka sensor akan hanya membaca nilai suhu sebesar -127 C. Merujuk dari tabel 1 hasil pengujian sensor DS18B20 dengan thermometer tubuh memiliki nilai error sebesar 4,07\%.

\section{B. Load Cell $5 \mathrm{~kg}$}

Modul load cell $5 \mathrm{~kg}$ ini berperan sebagai pengukur berat badan bayi. Penggunaan load cell $5 \mathrm{~kg}$ digunakan, karena target pengguna dari inkubator ini adalah bayi yang memiliki berat badan di bawah rata - rata.

Pengujian modul load cell $5 \mathrm{~kg}$ ini dilakukan untuk mengetahui selisih antara modul dengan timbangan berat badan sehingga dapat diketahui seberapa besar tingkat akurasi yang dihasilkan modul load cell $5 \mathrm{~kg}$. Berat pada modul load cell ditampilkan pada serial monitor Arduino.

TABEL 2.

HASIl PENGUJian LOAD CELL 5 KG

\begin{tabular}{|c|c|c|c|c|}
\hline No & $\begin{array}{c}\text { Nilai Berat } \\
\text { pada Load } \\
\text { Cell 5 kg }\end{array}$ & $\begin{array}{c}\text { Nilai Berat } \\
\text { pada } \\
\text { Timbangan } \\
\text { Digital }\end{array}$ & Selisih & Error \\
\hline 1 & $0,4 \mathrm{~kg}$ & $0,40 \mathrm{~kg}$ & 0 & 0 \\
\hline 2 & $0,5 \mathrm{~kg}$ & $0,50 \mathrm{~kg}$ & 0 & 0 \\
\hline 3 & $0,9 \mathrm{~kg}$ & $0,90 \mathrm{~kg}$ & 0 & 0 \\
\hline 4 & $1,3 \mathrm{~kg}$ & $1,25 \mathrm{~kg}$ & 0,05 & $3,84 \%$ \\
\hline 5 & $1,2 \mathrm{~kg}$ & $1,25 \mathrm{~kg}$ & 0,05 & $4,16 \%$ \\
\hline 6 & $1,4 \mathrm{~kg}$ & $1,45 \mathrm{~kg}$ & 0,05 & $3,57 \%$ \\
\hline 7 & $1,7 \mathrm{~kg}$ & $1,85 \mathrm{~kg}$ & 0,15 & $8,8 \%$ \\
\hline 8 & $1,5 \mathrm{~kg}$ & $1,55 \mathrm{~kg}$ & 0,05 & $3,33 \%$ \\
\hline 9 & $3,1 \mathrm{~kg}$ & $3,00 \mathrm{~kg}$ & 0,1 & $3,22 \%$ \\
\hline
\end{tabular}




\begin{tabular}{|c|c|c|c|c|c|}
\hline 10 & $4,4 \mathrm{~kg}$ & $4,50 \mathrm{~kg}$ & 0,1 & $2,27 \%$ & perangkat smartphone dengan mengklik tombol bluetooth \\
\hline \multicolumn{3}{|c|}{ RATA - RATA ERROR } & 0,055 & $2,91 \%$ & dari aplikasi MIT APP seperti yang ditunjukkan Gambar 6.
\end{tabular}

Penggunaan modul HX711 pada load cell dibutuhkan, untuk menguatkan sinyal yang diberi oleh load cell agar dapat dibaca dan diproses oleh Arduino. Dari hasil percobaan load cell dengan timbangan digital pada tabel 2 memiliki nilai rata - rata error sebesar $2,91 \%$

\section{Easy Pulse Plugin}

Sensor detak jantung ini berperan sebagai pengukur detak jantung tubuh bayi. Pengujian sensor detak jantung ini dilakukan untuk mengetahui selisih antara modul sensor detak jantung dengan oximeter sesungguhnya sehingga dapat diketahui seberapa besar tingkat akurasi yang dihasilkan sensor suhu detak jantung ini. Detak jantung pada modul sensor ditampilkan pada serial monitor Arduino.

Tabel 3. Hasil Pengujian Easy Pulse Plugin

\begin{tabular}{|c|c|c|c|c|c|}
\hline No & Nama & $\begin{array}{c}\text { Nilai } \\
\text { Pulse } \\
\text { Sensor }\end{array}$ & $\begin{array}{c}\text { Nilai } \\
\text { Oximeter }\end{array}$ & Selisih & Error \\
\hline 1 & A & $78 \mathrm{bpm}$ & $77 \mathrm{bpm}$ & 1 & $1,28 \%$ \\
\hline 2 & $\mathrm{~B}$ & $78 \mathrm{bpm}$ & $77 \mathrm{bpm}$ & 1 & $1,28 \%$ \\
\hline 3 & $\mathrm{C}$ & $93 \mathrm{bpm}$ & $91 \mathrm{bpm}$ & 2 & $2,15 \%$ \\
\hline 4 & $\mathrm{D}$ & $72 \mathrm{bpm}$ & $75 \mathrm{bpm}$ & 3 & $4,16 \%$ \\
\hline 5 & $\mathrm{E}$ & $90 \mathrm{bpm}$ & $93 \mathrm{bpm}$ & 3 & $3,33 \%$ \\
\hline 6 & $\mathrm{~F}$ & $93 \mathrm{bpm}$ & $94 \mathrm{bpm}$ & 1 & $1,07 \%$ \\
\hline 7 & $\mathrm{G}$ & 117 & $118 \mathrm{bpm}$ & 1 & $0,85 \%$ \\
\hline 8 & $\mathrm{H}$ & $87 \mathrm{bpm}$ & $87 \mathrm{bpm}$ & 0 & $0 \%$ \\
\hline 9 & $\mathrm{I}$ & $75 \mathrm{bpm}$ & $79 \mathrm{bpm}$ & 4 & $5,33 \%$ \\
\hline 10 & \multicolumn{6}{|c|}{ J } & $96 \mathrm{bpm}$ & $97 \mathrm{bpm}$ & 1 & $1,04 \%$ \\
\hline \multicolumn{7}{|c|}{ RATA ERROR } & 1,6 & $2,04 \%$ \\
\hline
\end{tabular}

Untuk melakukan pengukuran detak jantung, Pulse sensor dan oximeter diletakkan di ujung jari telunjuk. Hal ini dilakukan, karena ujung jari memiliki kulit yang tipis, sehingga sinar infra red dari easy pulse plugin dan oximeter dapat mendeteksi denyut pada jari. Untuk mendapatkan nilai yang stabil baik dari pulse sensor dan oximeter membutuhkan waktu 20 detik. Berdasarkan tabel 3, dari hasil percobaan antara easy pulse plugin dengan oximeter memiliki nilai rata - rata error $2,04 \%$.

\section{Aplikasi MIT APP}

Aplikasi MIT APP pada penelitian ini digunakan sebagai interface/antarmuka untuk menampilkan parameter yang terukur dari setiap sensor. MIT APP Inventor digunakan sebagai Bluetooth Client untuk menerima data.

Pengujian MIT APP dilakukan untuk mengetahui apakah data yang dikirimkan dapat diterima atau tidak oleh aplikasi. Pengujian dilakukan dengan cara menginstal aplikasi yang telah dibuat ke smartphone Android. Untuk menjalankan aplikasi, pertama pasangkan terlebih dahulu



Gambar 6. Pemasangan Perangkat Bluetooth

Setelah perangkat berhasil dipasangkan, maka tampilan aplikasi akan berubah menjadi seperti Gambar 7.

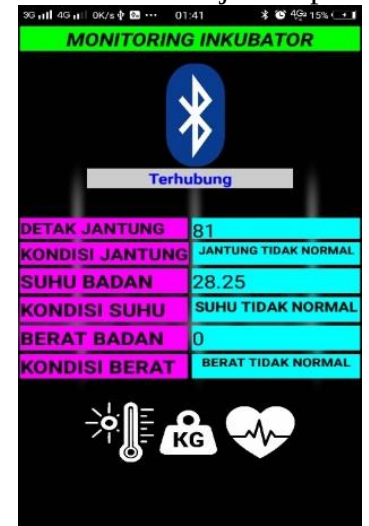

Gambar 7. Tampilan Interface Aplikasi MIT APP

Dapat terlihat bahwa data dari setiap sensor dapat terkirim ke perangkat smartphone pengguna.

Pengujian keseluruhan dilakukan untuk mengetahui apakah sistem yang telah dibuat bekerja sesuai dengan yang direncanakan atau tidak. Pengujian ini meliputi Sensor Easy Pulse Plugin, Load Cell, Sensor DS18B20, dan Bluetooth Module HC-05. Pengujian dilakukan dengan cara melihat tampilan dari LCD dan interface dari aplikasi yang telah dibuat di MIT APP. Hasil pengujian keseluruhan dapat dilihat pada tabel 4 .

TABEL 4. HASIL PENGUJIAN SISTEM MONITORING INKUBATOR

\begin{tabular}{|c|c|c|c|c|c|c|c|c|c|c|}
\hline \multirow{2}{*}{$\begin{array}{c}\text { Data } \\
\text { Pembacaan }\end{array}$} & \multicolumn{3}{|c|}{ Berat Badan } & \multicolumn{3}{|c|}{ Suhu Tubuh } & \multicolumn{3}{|c|}{ Detak Jantung } & \multirow[b]{2}{*}{ Bluetooth } \\
\hline & $\begin{array}{c}\text { Load Cell } \\
(I C D)\end{array}$ & $\begin{array}{c}\text { Timbangan } \\
\text { digital }\end{array}$ & $\begin{array}{l}\text { Level } \\
\text { (AIT } \\
\text { APP) }\end{array}$ & $\begin{array}{c}\text { DS18B20 } \\
\text { (LCD) }\end{array}$ & $\begin{array}{c}\text { Thermometer } \\
\text { digital }\end{array}$ & $\begin{array}{l}\text { Level } \\
\text { (AIT } \\
\text { APP) }\end{array}$ & $\begin{array}{l}\text { Pulse } \\
\text { Sensor } \\
\text { (LCD) }\end{array}$ & Oximeter & $\begin{array}{l}\text { Level } \\
\text { (MIT } \\
\text { APP) }\end{array}$ & \\
\hline A & $1,2 \mathrm{~kg}$ & $1,25 \mathrm{~kg}$ & 1 & $33,3^{\circ} \mathrm{C}$ & $36,7^{\circ} \mathrm{C}$ & 1 & $73 \mathrm{bpm}$ & $73 \mathrm{bpm}$ & 1 & terhubung \\
\hline B & $1,3 \mathrm{~kg}$ & $1,40 \mathrm{~kg}$ & 1 & $33,6^{\circ} \mathrm{C}$ & $34,8^{\circ} \mathrm{C}$ & 1 & $72 \mathrm{bpm}$ & $75 \mathrm{bpm}$ & 1 & terhubung \\
\hline $\mathrm{C}$ & $1,7 \mathrm{~kg}$ & $1,55 \mathrm{~kg}$ & 1 & $32,5^{\circ} \mathrm{C}$ & $33,4^{\circ} \mathrm{C}$ & 1 & $78 \mathrm{bpm}$ & $77 \mathrm{bpm}$ & 1 & terhubung \\
\hline D & $2,6 \mathrm{~kg}$ & $2,75 \mathrm{~kg}$ & 2 & $32,2^{\circ} \mathrm{C}$ & $33,7^{\circ} \mathrm{C}$ & 1 & $93 \mathrm{bpm}$ & $91 \mathrm{bpm}$ & 1 & terhubung \\
\hline$E$ & $4,0 \mathrm{~kg}$ & $4,30 \mathrm{~kg}$ & 2 & $33,5^{\circ} \mathrm{C}$ & $34,8^{\circ} \mathrm{C}$ & 1 & $90 \mathrm{bpm}$ & $93 \mathrm{bpm}$ & 1 & terhubung \\
\hline
\end{tabular}

Berdasarkan tabel 4 dapat dilihat bahwa terdapat dua level yang menjelaskan tentang kondisi dari masing - masing pembacaan sensor. Level 1 menandakan bahwa kondisi dari 
objek yang dibaca tidak normal, sedangkan level 2 menandakan kondisi dari objek yang dibaca normal. Kondisi dari setiap pembacaan data sensor akan dikirimkan ke aplikasi MIT APP yang dihubungkan melalui bluetooth. Adapun pembacaan kondisi normal adalah ketika berat badan lebih dari $2.5 \mathrm{~kg}$, suhu tubuh lebih dari 36,6, dan detak jantung lebih dari 120 bpm.

\section{KESIMPULAN}

Dari penelitian yang telah dilakukan dapat disimpulkan pengujian nilai sensor DS18B20 memiliki nilai rata - rata error sebesar 2,04 \%. Pengujian nilai load cell memiliki nilai rata - rata error sebesar 6,90 \%. Pengujian nilai sensor Easy Pulse Plugin memiliki nilai rata - rata error sebesar 5,79 \%. Pengujian konektivitas Bluetooth, didapatkan bahwa maksimal jarak yang dapat dicapai untuk menghubungkan antar perangkat bluetooth adalah 8 meter dengan penghalang, dan 10 meter tanpa penghalang. Monitoring inkubator yang telah dilakukan ini dapat berjalan dengan baik.

\section{DAFTAR PUSTAKA}

[1] Berliana, Sarni Maniar. Faktor-Faktor Yang Memengaruhi Kelahiran Prematur Di Indonesia: Analisis Data Riskesdas 2013. E-journal widya kesehatan dan lingkungan. (2014)

[2] Sitohang, Nur Asnah. Asuhan Keperawatan Pada Bayi Berat Badan Lahir Rendah. Medan: Program Studi Ilmu Keperawatan. Universitas Sumatera Utara. (2004)

[3] Syahrul. "Pengembangan Inkubator Bayi Dan Sistem Pemantauan Remote”. Jurnal Tekno lnsentif Kopwil4, Vol. 6, No. 2, oktober. Unikom Bandung. (2012): 9-17.

[4] Sulistyo Ary, U. "Monitoring Baby Incubator Sentral dengan Komunikasi Wireless”, Jurnal Simetris, Vol. 9 No. 1 April (2018): 225 $-230$

[5] Dr. Marianti. “Kenali Tingkat Bilirubin Normal pada Bayi Baru Lahir”. www.alodokter.com/kenali-tingkat-bilirubin-normal-padabayi-baru-lahir (diakses tanggal 18 Februari 2019 pukul 12.50)

[6] Hidayati, Qory. "Intelligent Control System of Fire-Extinguishing and Obstacle-Avoiding Hexapod Robot”, Kinetik, 3, No.1 ( 2018), Pp. 110

[7] Andi Romi, W. (2018), "Rancang Bangun Alat Monitoring Suhu dan Kelembaban Pada Alat Baby Incubator Berbasis Internet Of Things”, Jurnal Teknologi, 6, (2018): 52 - 70 